\title{
Article \\ Relationship between the STEAM approach and SUMAK KAWSAY in vulne-rable social sectors
}

\author{
Galo Hurtado ${ }^{1,+, \ddagger(D)}$ \\ 1 Docente Investigador; gphurtado@sudamericano.edu.ec \\ * Correspondence: gphurtado@sudamericano.edu.ec; Tel.: +593-979-342-126 (EC)
}

\begin{abstract}
The research is based on the question: Can teaching/learning methodologies help to achieve the objective of Sumak Kawsay in Ecuador? a STEAM work approach was applied in technical high school students and higher education students (technological), in order to determine the level of impact in terms of project generation, following the entire process, from the generation of ideas to the linking of projects with society, The analysis was carried out in students from 15 to 22 years old in two institutions in the city of Cuenca, using the method of intentional sampling and the systematic review of scientific articles in the Scopus and Google academic databases of the last 3 years, to determine the level of impact of the prototypes pub-lished in indexed journals. The most striking aspect of the results is that of the 260 students surveyed, only $19.6 \%$ of students consider that there are STEAM teachers in the classroom, and only $56.92 \%$ of students manage to link their work with society, one of the recommended strategies being the publication of scientific articles and participation in congresses disseminating the high impact work done by students in the classroom.
\end{abstract}

Keywords: STEAM ; Teaching and learning ; Sumak Kawsay; vulnerable

\section{Introduction}

The technical training that students receive allows them to gene-rate a great diversity of projects, therefore, technology must be related to existing social problems and generate a solution through the use of technological tools, for which it is recom-mended to use different techniques and methodologies that have a series of processes that facilitate meeting the proposed objec-tives, in the research a STEAM approach was used to integrate the creativity of students with current technologies as a result of learning . At present, students take the subjects virtually, which made it easier to detect problems that exist in different social areas, and through the use of technology, solutions to these existing technological gaps are proposed. Another opportunity that arose in the virtuality that we are currently experiencing is the implementation of different methodological strategies that allow us to meet the objective of contributing to the teaching and learning methodology. STEAM teachers are considered to people who master one or more areas of the method, and who are able to determine op-portunities for projects in society that support in different strategic sectors improving the quality of life according to the article by (Jho et al., 2016) leads to open-mindedness of the teacher and institutional self-innovation in the significance of joint actions of social actors by maintaining a system of reciprocal relationship and continuous exchange of roles as mutual commitment, colla-borative nature, creation of digital educational materials and innovative dedication of learning strategies as a shared repertoi-re, explained in the article by (Santillán Aguirre et al., 2019), in the South American technological institute it is very easy to apply this STEAM method because in the training of students the five disciplines offered by the institution are included, on the contrary happens in the technical high schools that do relate the approaches but certain adaptations have had to be implemented by teachers so that this type of projects can be executed such as gamification, the use of simulators and other resources that facilitate the development of projects. In Ecuador it is still a new topic just in 2018 events were held, which generated an initiative in STEM to integrate it into the educational system, the three entities that have most promoted the use of this approach in educational institutions are educa-tion, STEM Academia Colombia, Siemens Stiftung, Red STEM Latinoamérica, and other entities that

Publisher's Note: MDPI stays neutra with regard to jurisdictional claims in published maps and institutional affiliations. 
from 2021, propose diffe-rent strategies for the implementation of STEM in the classroom of schools at the general level taking as a starting point the tech-nical high schools. As for the technical institutions of higher level it is easier to integrate all the aspects already of a STEAM approach, and that are related to the teaching learning metho-dologies for example with the ABP ( Project Based Learning) or a Design Thinking, everything depends on the type of project that is intended to be carried out, (Rodriguez et al., 2021) obtain as results the feasibility of the implementation of a STEAM ap-proach in Higher Education in Ecuador, there is a transversal axis of research, which affects the training of students through collaborative and multidisciplinary work, which will allow to integrate in an easy way this new approach and obtain results a new form of evaluation of students.

With the results of the theoretical review in the different data-bases, it was determined the feasibility of relating the use of STEAM, with the Sumak Kawsay in kiwcha and "good living" - in Spanish, which was incorporated in the new Constitution of Ecuador, and contain proposals that are formulated from the "gender equity" as a central approach, also a "fair trade", an "in-clusive education" and a "committed economy", (Cortez, 2011), taking into account these aspects in the research several field studies, electronic prototypes and mobile applications were developed, with the visually impaired, prototypes were developed to help in the teaching-learning methodology, we also wor-ked on the implementation of digital platforms that allow direct marketing to small producers avoiding intermediaries, and with the elderly, devices have been generated to help in senile de-mentia and studies of the current situation of the elderly and the use of new technologies, for the latter case, free software tools and social networks were used.

\section{Materials and Methods}

The students who participated were 340 students, divided into 260 technical high school students, 120 (1st year), 110 (2nd year), 30 (degree projects), and 80 students at the technological level, Of the total number of students participating in the techni-cal area, 35 are female and 65 are male. It should be noted that the selection of students for the different technical areas in the schools is done in the districts, In the area of technology, students have the faculty to select their career. At present, $75 \%$ of the students are men and only $25 \%$ are women who are studying technology in the technical areas.

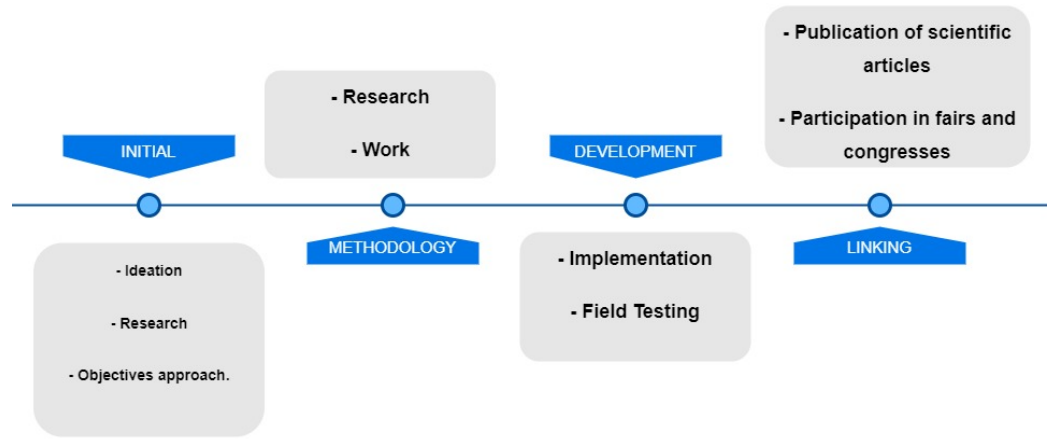

Figure 1. This is a figure. The scheme presented as a proposal allows to comply with the aspects: (a) Link projects with society. (b) It allows to integrate models and methods of teaching and learning in the development of projects.

In order to evaluate the projects, we worked with two aspects with the FIP (professional figures) in the case of the schools and with the knowledge integrating nuclei in the case of the technological ones, both aspects regulated under national eva-luation norms, which have the objective of guiding the teacher as to the minimum contents that the students have to know for the generation of projects, the integrated cores are the compilation of all the subjects for the development of activities, each subject contributes with a percentage to the final project, not always in the same dimension, this varies depending on the project to be implemented, the results of the projects are evaluated in two ways, the first is based on the level of impact, research and linkage with society, the second the students 
present in the so-called open houses, the results of the projects that are imple-mented throughout the school year. Sequential methodologies and concep-tual framework. As an aid to the project generation process, students are initially asked to make a pre-defense of the project, i.e., in a round table the students will present the projects they have in mind and the group of teachers from each area will determine the viability, feasibility and level of impact they can have, as well as make suggestions and recommendations regarding tools and technolo-gies they intend to use, based on experience, the market and the social extract in which they wish to implement the projects. The objective of this previous presentation is to ensure a good level of social impact of the projects they intend to implement and subsequently serve as a contribution to science with publica-tions of research results, the proposal to implement an ap-proach such as STEAM in the area of Software Development in the technological and technical baccalaureate in the areas of (consumer electronics, The Ministry of Education intends to implement ABP (Project Based Learning) in the technical bacca-laureate and in the higher education field, the ABP, Desing Thinking and other methodologies.

This process has been implemented as of the year 2020, result-ing in the publication of 8 scientific articles published in indexed journals and several projects that are being followed up in order to link them with society and subsequently publish the results. Currently the Ministry of Education through the department of continuing education promotes the course called "Training in Soft Skills and ABP" in order that students are able to generate innovation projects or ventures, whether collective or personal, all this in order to solve a latent social problem in the country such as unemployment, so far this year presents a figure of $5.7 \%$ unemployment nationwide, to achieve the goal of innovating the ABP has the following stages: Steps for the application of Problem Based Learning. According to Eggen and Kauchak (2015) the application of PBL in the classroom should be developed in 5 stages: Stage 1: Identify a question Stage 2: Generate hypothesis Stage 3: Gathering information Stage 4: Hypothesis evaluation Stage 5: Generalize Content closure in a problem-based learning class occurs when students tentatively generalize about the results based on the information. Over time, they develop a tolerance for complexity and ambiguity that can help them understand and cope with the complexities of life. Finally, it should be noted that, at the end of the last stage, Problem-Based Learning also provides opportuni-ties for the student to reflect on the process, and so the student can be expected to be able to transfer it to other classroom activities and also to his or her daily life, which is its own form of generalization.

\section{Results}

\subsection{Data analysis}

In the final stage of the research process, the data collected from the interviews were analyzed, as well as the results of the stu-dents' projects. It should be noted that the projects are always evaluated on the basis of the rubrics established by the institu-tions and related to the regulatory body such as the CES and the Ministry of Education. 


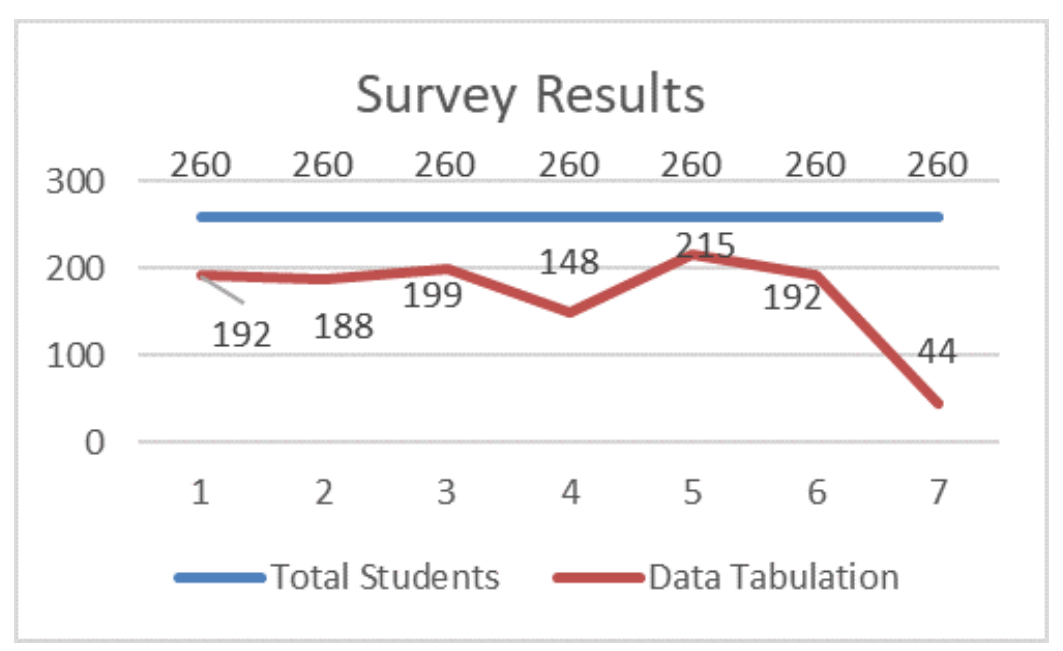

Figure 2. This graph shows the results of the student surveys. The items correspond to :(a) Total number of respondents (b) The affirmative responses for each parameter proposed in the analysis.

The following is a detail of each of the seven parameters used in the survey applied to both high school and technological students:

Table 1. There are seven points proposed in the analysis

\begin{tabular}{cc}
\hline Number & Analysis items \\
\hline 1 & Digital Tools \\
2 & STEAM \\
3 & Use of Technology in the classroom \\
4 & Project Linkage \\
5 & Economic Resources \\
6 & Knowledge of Teaching and Learning methodologies \\
7 & STEAM teachers \\
\hline
\end{tabular}

\subsubsection{Statistical analysis}

The analysis of the results of the student surveys yielded the following data: 


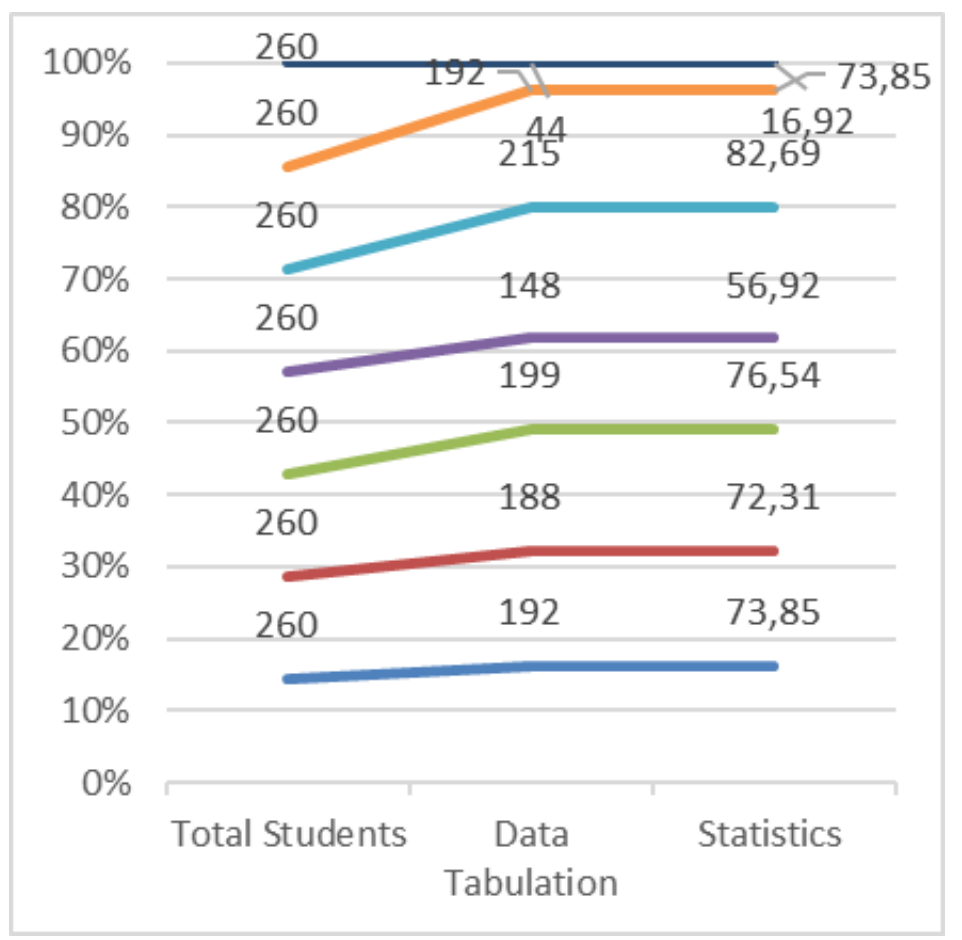

Figure 3. This graph represents the statistical analysis of the analysis parameters :(a) Interpretation of the data (b) The affirmative answers with their respective percentages.

The projects that were obtained as a result of the work of the entire academic period were taken into account, for the tabula-tion of data was made based on the total number of students surveyed in relation to the answers to each of the questions, obtaining as a result the third value which would be the statistical response.

The parameters of analysis in the research are:

- Use of Digital tools;

- STEAM;

- Use of Technology in classes;

- Project linkage;

- Economic Resources;

- They know teaching-learning methodologies;

- $\quad$ STEAM teachers;

Interpretation and analysis of the results of each parameter:

1. $73.85 \%$ of students agreed that currently, due to different factors such as the pandemic, teachers have incorporated the use of digital tools in the classroom, including the term gamification in the teaching and learning process. ;

2. $72.31 \%$ of students mentioned that they are applying the STEAM approach in the projects they generate, integrating the majority of subjects, that is to say, as a project that integrates knowledge.;

3. $76.54 \%$ of students do use some technological resource in the classroom, however in this aspect the economic situation of the students must be considered, in some cases the same student shares a mobile device with several members of the household to receive classes, due to the current pandemic.

4. $56.92 \%$ of students mention that there is a linkage of the pro-jects, that is, if they solve an existing social problem through technology.

5. $82.69 \%$ of the students mentioned that they are indeed able to acquire materials to develop the projects and put them into operation.

6. $73.89 \%$ mentioned that they have indeed heard of these meth-odologies, especially that there is a lot of talk about the inverted classroom, which is a term that has been heard since virtuality. 
7. Only $16.9 \%$ of students consider that the teachers who teach the classes can be considered STEAM teachers. It should be noted that in the previous discussion and training, it has been men-tioned which are the aspects of a STEAM teacher based on (Cortez, 2011)..

\section{Discussion}

Once the analysis of the data collected from the surveys and the analysis of Sumak Kawsay was done, it was determined that there is a considerable social problem according to the data collected by the National Council for the Equality of Disabilities of Ecuador. 047b people registered in groups of vulnerable sectors and in Azuay in the canton of Cuenca, where the research was carried out, there are 20,221 people who belong to the group of people with some type of vulnerability and of which $29.36 \%$ are older adults and $17.8 \%$ are in a range of 10 to 24 years, and only $40 \%$ of members of these social sectors are studying, Therefore, the parameters established in the Sumak Kawsay are not met, and it is an opportunity for the different projects, electronic devices, web and mobile applications that are developed in the institutes and schools to contribute to a more comprehensive compliance with the plan of good living.

\section{Conclusions}

Teacher training is the key to quality education and the change in the traditional teaching and learning model forced teachers to incorporate digital tools, teachers are ready for these changes are called digital students, They have a wide mastery of techno-logical tools which facilitates the integration of new tools that accompanied by a planning will generate social impact projects that can contribute to the fulfillment of the "Plan of Good Living" or Sumak Kawsay that with a STEAM approach and the use of appropriate tools can solve problems, generate entrepreneur-ship or contribute to the development of the productive matrix of the country. Currently in the planning of the Ministry of Edu-cation is already suggested the use of some digital tools such as TINKERCARD which is an online platform that allows the de-velopment of basic electronics projects and as you progress you can use different microcontrollers, also integrates 3D modeling and at the same time Scratch is used as a basic programming tool, that is, in the classroom gamification is integrated.

Funding: "This research has been funded by the Instituto Tecnologico Particular Sudamericano de la ciudad de Cuenca"

Institutional Review Board Statement: In this section, please add the Institutional Review Board Statement and approval number for studies involving humans or animals. Please note that the Editorial Office might ask you for further information. Please add "The study was conducted according to the guidelines of the Declaration of Helsinki, and approved by the Institutional Review Board (or Ethics Committee) of NAME OF INSTITUTE (protocol code XXX and date of approval)." OR "Ethical review and approval were waived for this study, due to REASON (please provide a detailed justification)." OR "Not applicable" for studies not involving humans or animals. You might also choose to exclude this statement if the study did not involve humans or animals.

Informed Consent Statement: The study was conducted at the Ricaurte High School with students in the area of mechatronics, all data collected were worked on google forms anonymously because the Code of Childhood and Adolescence does not allow the dissemination of images or names of minors without prior authorization of legal guardians, and the other part of the research was developed in the South American Particular Technology of Cuenca in this case the respondents are students of legal age of the career of Software Development who participated freely and voluntarily, As for the teachers who participated, there is a letter of invitation to participate in the research in which the objective and scope of the publication was made known, with the respective endorsements of the interviews conducted by the zoom platform due to the pandemic in which we find ourselves to date.

Data Availability Statement: The information such as videos of the interviews, surveys, bibliographic reviews and others are stored in a google drive that will be shared when the reviewers request them. 
Acknowledgments: To the students and teachers from different parts of the country who contributed to the development of the research, to the institution where I currently work for the financing of materials and tools used in the project for the collection of information, to my wife and son for their unconditional support.

Conflicts of Interest: "Los autores declaran no tener ningún conflicto de intereses". "Los financiadores no tuvieron ningún papel en el diseño del estudio; en la recogida, análisis o interpretación de los datos; en la redacción del manuscrito o en la decisión de publicar los resultados".

\section{Abbreviations}

The following abbreviations are used in this manuscript:

ABP Project Based Learning

FIP Professional Figure

CES Higher Education Council

CACES Council for Quality Assurance in Higher Education

\section{References}

1. Beltrán, Jesús, and others. 1996. Procesos, Estrategias y Técnicas de Aprendizaje. Sintesis Madrid.

2. Brown, Tim, and others. 2008. "Design Thinking." Harvard Business Review 86 (6): 84.

3. Candel, Inmaculada, María D. Marcos, Ramón Martínez-Máñez, Félix Sancenón, Ana M. Costero, Margartita Parra, Salvador Gil, Carmen Guillem, Francisco Pérez-Plá, and Pedro Amorós. 2015. Microporous and Mesoporous Materials. https://www.sciencedirect.com/science/article/pii/S138

4. Cortés, Albenis. 2018. “Semillero STEAM Cisco.” Magazın Aula Urbana, no. 110: 12.

5. Crespo, Galo Hurtado, Juan Pérez Pérez, and Zoila Contreras Paguay. 2020. "Comparación de Rendimiento de Antenas Microstrip Con Diferentes Frecuencias y Polarización." Ciencia Digital 4 (3): 107-16.

6. Elsevier, ed. n.d. “Una Nueva Medida de Similitud de Oraciones y Una Técnica de Extracción Basada En Oraciones Para El Resumen Automático Del Texto." Sistemas Expertos Con Aplicaciones.

7. Gómez, Bernardo Restrepo. 2005. “Aprendizaje Basado En Problemas (ABP): Una Innovación Didáctica Para La Enseñanza Universitaria." Educación y Educadores, no. 8: 9-20.

8. Houtart, François. 2011. "El Concepto de Sumak Kawsay (Buen Vivir) y Su Correspondencia Con El Bien Común de La Humanidad." Ecuador Debate 84 (57-76).

9. Hurtado, Galo, Max Zuñiga, and Santiago Durazno. 2020. "Implementación de Indicadores de Gestión Por Procesos Para Empresas de Desarrollo de Software." Revista Publicando 7 (25): 170-79.

10. Jho, Hunkoog, Oksu Hong, and Jinwoong Song. 2016. “An Analysis of STEM/STEAM Teacher Education in Korea with a Case Study of Two Schools from a Community of Practice Perspective." Eurasia Journal of Mathematics, Science and Technology Education 12 (7): 1843-62. https://doi.org/10.12973/EURASIA.2016.1538A.

11. Kim Yilip y Park, Namje. n.d. "El Efecto de La Educación STEAM En La Mejora de La Creatividad de Los Estudiantes de La Escuela Primaria." In Aplicaciones Informáticas Para Seguridad, Control e Ingeniería de Sistemas, edited by Springer.

12. MartRodr, Dianelkys, and Dora Lilia Márquez Delgado. 2014. "Las Habilidades Investigativas Como Eje Transversal de La Formación Para La Investigación."

13. Monroy-González, Luz A, Luz-E Mendoza-Hernández, and Hugo Alarcón-Acosta. 2021. "Educación STEAM En Preparatoria." Uno Sapiens Boletın Cientıfico de La Escuela Preparatoria No. 14 (7): 12-15.

14. Muñoz-Repiso, Ana Garc-Valcárcel. 2007. “Herramientas Tecnológicas Para Mejorar La Docencia Universitaria. Una Reflexión Desde La Experiencia y La Investigación." RIED. Revista Iberoamericana de Educación a Distancia 10 (2): 125-48.

15. Park HyunJu y Byun, Soo-yong y Sim Jaeho y Han Hye-Sook y Baek Yoon Su. n.d. "Percepciones y Prácticas de Los Profesores Sobre La Educación STEAM En Corea Del Sur." Edited by Modestum Publishing LTD. Eurasia Journal of Mathematics, Science and Technology Education.

16. Pastor, VManuel López, Miriam Molina, Cristina Pascual Arias, and Juan Carlos Manrique Arribas. 2020. “La Importancia de Utilizar La Evaluación Formativa y Compartida En La 
Formación Inicial Del Profesorado de Educación Fisica: Los Proyectos de Aprendizaje Tutorado Como Ejemplo de Buena Práctica." Retos: Nuevas Tendencias En Educación Fisica, Deporte y Recreación, no. 37: 620-27.

17. Raj, V. Bhasker, Harpreet Singh, A.T. Nimal, Monika Tomar, M.U. Sharma, and Vinay Gupta. 2015. "Ref 22." Sensors and Actuators B: Chemical. https://www.sciencedirect.com/science/article/pii/ 18. Rojas Bonilla, Gustavo Félix. 2011. “Uso Adecuado de Estrategias Metodológicas En El Aula."

19. Romero-Ariza Marta y Quesada, Antonio y Abril Ana-Mar ' i a y Cobo Cristina. 2021. “Cambios En La Autoeficacia, Creencias y Prácticas de Los Maestros a Través Del Desarrollo Profesional de Maestros STEAM (Cambios En La Autoeficacia, Creencias y Pr 'a Cticas Docentes En La Formaci ó n STEAM de Profesorado)." Edited by Taylor Francis. Journal for the Study of Education and Development.

20. Santillán Aguirre, Juan Patricio, Valeria del Carmen Cadena Vaca, and Miguel Cadena Vaca. 2019. “Educación Steam: Entrada a La Sociedad Del Conocimiento." Ciencia Digital 3 (3.4.): 212-27. https://doi.org/10.33262/CIENCIADIGITAL.V3I3.4..847.

21. Telefónica, Fundación. 2020. Sociedad Digital En España 2019. Fundación Telefónica.

22. Valdivia Garc, César Alonso. 2015. “Modelo de Monitoreo y Asesoramiento Pedagógico Para Mejorar El Desempeño Docente En Educación Secundaria-Chiclayo-2015."

23. Vanhulst, Julien. 2015. “El Laberinto de Los Discursos Del Buen Vivir: Entre Sumak Kawsay y Socialismo Del Siglo XXI." Polis. Revista Latinoamericana, no. 40.

24. Vega, Fernando. 2014. “El Buen Vivir-Sumak Kawsay En La Constitución y En El PNBV 2013-2017 Del Ecuador." OBETS: Revista de Ciencias Sociales 9 (1): 167-94.

25. Zúñiga, Max Renato Renato, Galo Patricio Patricio Hurtado, and Juan Marcelo Pérez. 2020. “La Capacidad de La Gestión de La Configuración En Las Pequeñas Organizaciones de Desarrollo de Software." ConcienciaDigital 3 (3): 466-85. 
